\title{
Frequency of episodic memories as a function of their age*
}

\author{
HERBERT F. CROVITZ \\ VA Hospital, Durham, North Carolina 27705 \\ and \\ HAROLD SCHIFFMAN \\ Duke University, Durham, North Carolina 27705
}

\begin{abstract}
Ninety-eight undergraduates were given a list of 20 common English nouns and told to inspect each word until a specific episodic memory associated with it came to mind, and to write a few words to identify that memory. After finishing the list, they were asked to go back and to date the episodic memories as accurately as they could. The frequency of memories as a function of their age was found to be $\log \log$ linear, with the frequency inversely related to the age of memory.
\end{abstract}

It would be desirable to expose by listing, the full store of episodic memory. Such a list should include the age of each memory as referred to the present. If we were now to examine the distribution of memories as a function of their age, there is reason to believe the frequency of the more aged memories would be reduced.

Galton $(1879 \mathrm{a}, 1879 \mathrm{~b})$ in a study of his own memorial process, developed the method of unconstrained search to allow him to sample his store of episodic memory. His method consisted of inspecting a word until an association to it was made. If that association referred to an event remembered from his past, he dated that memory. At the time Galton carried out this study, he was 57 years old and, using only three coarse time intervals, found that $39 \%$ of the memories were dated prior to the age of $22,46 \%$ were from subsequent manhood, and $15 \%$ were reported by him to refer to "quite recent events."

The stimulus words which Galton used were not common ones which were likely to refer to events common to all times of life, and his three categories were arbitrary. We sought to develop Galton's method as an unbiased probe in to the store of episodic memory and to treat the reported ages of memories in an unbiased and meaningful way.

\section{METHOD}

\section{Subjects}

Subjects were 98 undergraduates from Duke University who were run in groups of about 20 each.

\section{Word list}

The stimulus list was a random set of 20 of the 29 English words of extreme familiarity all having the features of being in the set of basic English picturable nouns (Ogden, 1934), having a score of at least 6.00 on $\mathrm{I}$, and $\mathrm{C}$, and $\mathrm{M}$, in the word list of

*This work is from the Veterans Administration Hospital, Durham, North Carolina, Program Number 1620-01.
Paivio, Yuille, and Madigan (1968), and being rated A or AA in Thorndike-Lorge frequency.

\section{Instructions}

The subjects were read a statement saying this was a study of their personal memories, that they were to inspect a set of words one by one, and to note down a word or two describing the memory associated to each word that first came to mind. At the end of this inspection of the list, they were asked to date each memory as accurately as they could. Subjects required about $10 \mathrm{~min}$ to do the memory search and about $5 \mathrm{~min}$ to ascribe ages to the mem ories they had retrieved.

\section{RESULTS AND DISCUSSION}

The ages of the memories were reported in terms of numbers of natural language time-measuring words: seconds, minutes, hours, days, weeks, months, and years ago. Table 1 shows the frequency of the ages of the episodic memories in the time-measuring categories emitted by the subjects. For example, 29 of the 1745 scorable episodes were dated $1 \mathrm{~h}$ ago, while 3 were dated $7 \mathrm{~h}$ old.

The precise meaning of the time-measuring words appears to be more nearly attained when they are considered as classes which each have a class interval and a class mark. In this paper we assume that the class interval expresses a temporal wid th corresponding to the time-measuring word. For example, a memory reported as referring to an event occurring $7 \mathrm{~h}$ ago is assumed to have an uncertainty of $1 \mathrm{~h}$; i.e., plus or minus $.5 \mathrm{~h}$ around the class mark of $7 \mathrm{~h}$.

We further assume that the frequency distribution of episodic memories is square within a class; i.e., that it is equiprobable that a memory appears at any position within that class. Since the subjects in this study reported memories at the class marks, we redistributed this frequency equally over the appropriate interval, and all memories less than $1 \mathrm{~h}$ old were collapsed into the 
Table 1

Frequency of Memories Ascribed to Natural Language Categories

\begin{tabular}{rrrrrr}
\hline $\begin{array}{c}\text { Cate- } \\
\text { gory }\end{array}$ & $\begin{array}{c}\text { Fre- } \\
\text { quency }\end{array}$ & Category & $\begin{array}{c}\text { Fre- } \\
\text { quency }\end{array}$ & Category & $\begin{array}{r}\text { Fre- } \\
\text { quency }\end{array}$ \\
\hline $1 \mathrm{sec}$ & 2 & $18 \mathrm{~h}$ & 1 & 7 months & 5 \\
$15 \mathrm{sec}$ & 2 & $20 \mathrm{~h}$ & 1 & 8 months & 13 \\
$1 \mathrm{~min}$ & 5 & 1 day & 124 & 9 months & 17 \\
$2 \mathrm{~min}$ & 1 & 2 days & 41 & 10 months & 6 \\
$5 \mathrm{~min}$ & 15 & 3 days & 25 & 11 months & 6 \\
$8 \mathrm{~min}$ & 1 & 4 days & 19 & 14 months & 1 \\
$10 \mathrm{~min}$ & 2 & 5 days & 13 & 1 year & 127 \\
$15 \mathrm{~min}$ & 2 & 6 days & 9 & 2 years & 117 \\
$20 \mathrm{~min}$ & 3 & 7 days & 1 & 3 years & 74 \\
$30 \mathrm{~min}$ & 12 & 8 days & 3 & 4 years & 74 \\
$45 \mathrm{~min}$ & 3 & 9 days & 3 & 5 years & 55 \\
$1 \mathrm{~h}$ & 29 & 10 days & 1 & 6 years & 53 \\
$2 \mathrm{~h}$ & 29 & 1 week & 71 & 7 years & 38 \\
$3 \mathrm{~h}$ & 12 & 2 weeks & 43 & 8 years & 51 \\
$4 \mathrm{~h}$ & 9 & 3 weeks & 27 & 9 years & 45 \\
$5 \mathrm{~h}$ & 4 & 4 weeks & 4 & 10 years & 82 \\
$6 \mathrm{~h}$ & 5 & 5 weeks & 2 & 11 years & 30 \\
$7 \mathrm{~h}$ & 3 & 6 weeks & 1 & 12 years & 36 \\
$8 \mathrm{~h}$ & 2 & 1 month & 71 & 13 years & 27 \\
$11 \mathrm{~h}$ & 1 & 2 months & 58 & 14 years & 27 \\
$12 \mathrm{~h}$ & 6 & 3 months & 56 & 15 years & 22 \\
$13 \mathrm{~h}$ & 2 & 4 months & 24 & 16 years & 8 \\
$14 \mathrm{~h}$ & 1 & 5 months & 22 & 17 years & 6 \\
$16 \mathrm{~h}$ & 1 & 6 months & 53 & & \\
\hline
\end{tabular}

class of $1 \mathrm{~h}$ old to simplify further analysis. It appears that the temporal classes are arranged so that the more remote classes span greater temporal intervals and thus may have poorer psychological resolving power (Gravetter \& Lockhead, 1973).

Figure 1 is a plot of the log of the class frequency as a function of the log of the class mark in hours ago. It is quite regular with a slope of -.78 and an intercept of 1.42 , yielding the equation

$$
y=-.78 \chi+1.42
$$

where $\chi$ is the $\log$ of the class mark and $y$ is the $\log$ of the class frequency.

In the present study we have indeed found that the frequency of episodic memories markedly and regularly decreases as a function of their age. Since subjects in this



Fig. 1. Log of class frequency as a function of $\log$ of class mark in hours ago.

experiment were all young adults, no statements can yet be made about the form of the store in the population in general. Also, the age of our Ss inhibits a meaningful comparison between the results of this study and Galton's figures.

\section{REFERENCES}

Galton, F. Psychometric experiments. Brain, 1879, 2, 148-162. Galton, F. Psychometric facts. The Nineteen th Century, 1879, 5, 425-433.

Gravetter, F., \& Lockhead, G. R. Criterial range as a frame of reference for stimulus judgment, Psychological R eview, 1973, 80, 203-216.

Ogden, C. K. The system of basic English, New York: Harcourt, Brace \& World, 1934.

Paivio, A., Yuille, J. C., \& Madigan, S. A. Concreteness, imagery, and meaningfulness value for 925 nouns, Journal of Experimental Psychology Monograph Supplement, 1968, 76, 1, 1-25.

(Received for publication September 11, 1974.) 